\title{
SASTRA 'MUNGKIN': KONTESTASI SIMBOLIK ANDREA HIRATA DALAM ARENA SASTRA INDONESIA
}

\author{
Kukuh Yudha Karnanta \\ Kajian Sastra dan Budaya, Fakultas Ilmu Budaya, Universitas Airlangga \\ Jalan Dharmawangsa Dalam \\ Email:ky_karnanta@yahoo.co.id
}

\begin{abstract}
Abstrak
Artikel berjudul Sastra 'Mungkin': Kontestasi Simbolik. Andrea Hirata dalam Arena Sastra Indonesia membahas praktik bersastra Andrea Hirata, penulis novel yang namanya 'mengorbit' dalam kesastraan Indonesia sejak 2006 hingga kini. Tujuan penelitian ini adalah mengeksplisitkan pandanganpandangan dan kontestasi yang dipraktikkan Andrea Hirata berdasarkan pandangannya tersebut dalam mendapatkan legitimasi atas kiprahnya sebagai penulis karya sastra. Penelitian ini menggunakan teori Arena Produksi Kultural Pierre Bourdieu yang mengasumsikan bahwa sastra bukan sekadar persoalan estetika, melainkan juga pergulatan posisi antara agen-agen yang beroperasi dalam arena sastra. Dari penelitian yang dilakukan, artikel ini mengungkapkan bahwa Andrea Hirata sesungguhnya memiliki tendensi, bahkan obsesi, untuk meraih legitimasi spesifik sebagai seorang 'sastrawan'. Untuk itu, Andrea Hirata mendesakkan pandangan tentang possibility dalam sastra Indonesia
\end{abstract}

Kata kunci: Arena, Andrea Hirata, kekerasan simbolik, legitimasi, doksa, heterodoksa

\section{Abstract}

The article entitled Sastra 'Mungkin': A Symbolic contestation of Andrea Hirata in Indonesian Literature Arena is discussing the literary practices of Andrea Hirata, a novelist who surprisingly popular in Indonesian literature from 2006 to present. This article aims to explicit the views and contestation of Andrea Hirata literary practices based on his views in gaining legitimacy of his works as an author. This research applies Pierre Bourdieu's Arena Cultural Production, which assumes that literature is not just a question of aesthetics but also the struggle of positions between agents operating in the literary arena. According to the research that has been conducted, the result reveals that Andrea Hirata actually has a tendency, furthermore, obsession, in order to gain a specific legitimacy as an author (literary figure). In doing so, Andrea Hirata impose his views about possibility in Indonesian literature.

Keywords: field, Andrea Hirata, symbolic violence, legitimacy, doxa, heterodoxa

\section{Pendahuluan}

Andrea Hirata (Andrea) merupakan salah satu novelis Indonesia yang secara konsisten mempublikasikan karyanya. Sejak menerbitkan tetralogi Laskar Pelangi, Sang Pemimpi, Edensor, dan Maryamah Karpov pada tahun 2010, penulis asal Belitong itu menerbitkan dwilogi Padang Bulan dan Cinta di dalam Gelas yang dilanjutkan dengan penerbitan novel 11 Patriot pada tahun 2011. Tetralogi Laskar Pelangi bahkan menjadi karya fenomenal yang terjual mencapai lebih dari 20 juta kopi. Produktivitas Andrea tersebut agaknya terkait erat dengan keterlibatannya dalam arena seni lainnya, seperti film dan seni pertunjukan. Andrea terlibat langsung dalam proyek transformasi karya-karyanya ke dalam media film, serial televisi, pentas musikal, dan bahkan festival kebudayaan dengan judul yang sama dengan karyanya, Laskar Pelangi. Novel Laskar Pelangi dan Sang Pemimpi merupakan dua novelnya yang telah ditransformasikan ke dalam bentuk film yang mana menuai apresiasi serta prestasi, baik di dalam maupun di luar negeri.

Andrea Hirata (AH) dan karyanya, tetralogi Laskar Pelangi, muncul pada era 20062010 yang mana kondisi ruang sosial Indonesia saat itu ditandai dengan jumlah dan pengaruh masyarakat kelas-menengah yang semakin menguat. Adapun struktur arena sastra Indonesia yang menjadi latar praktik bersastra AH terkonfigurasi kelompok-kelompok sastra yang, katakanlah, legitimit: Dewan Kesenian 


\section{Jurnal Poetika Vol. III No. 2, Desember 2015}

Jakarta, Teater Utan Kayu, Majalah Horison, Taman Ismail Marzuki (TIM), Boemipoetra, Gramedia, Kompas, dan lainnya. Kecuali pada event UbudWriters Festival2011 dan penghargaan Khatulistiwa Award 2007, yang itupun tak dimenanginya, nama $\mathrm{AH}$ nyaris senyap dalam pergaulan kelompok sastra legitimit. $\mathrm{AH}$ tampak tak terlalu ambil pusing dengan posisi serta status kepengarangannya yang belum juga 'sah' atau 'legitimit' sebagai sastrawan setara dengan, katakanlah, Ayu Utami, Seno Gumira Ajidarma, Agus Noor, atau Mashuri. Seakan menegaskan karakter Ikal, kuli ngambat yang dalam novelnya dikisahkan bermimpi berkuliah di Perancis, AH yang pernah bekerja sebagai pegawai BUMN dan berasal dari kelas menengah itu menyatakan bertekad hendak meraih nobel sastra dunia (metrotvnews 15/1/2012) dengan caranya sendiri.

Kiprah AH serupa di atas sesungguhnya menandakan suatu praktik 'pertarungan simbolik' yang terjadi antara satu sastrawan dengan struktur arena sastra yang menaunginya. Sosiolog sastra asal Perancis, Pierre Bourdieu (1995: 170) menjelaskan pertarungan simbolik dalam sastra sebagai "kuasa untuk mengubah dan menciptakan realitas, yakni mengubah dan menciptakannya sebagai sesuatu yang diakui, dikenali, dan juga sah. Kuasa simbolik untuk membuat orang melihat dan percaya, untuk memperkuat atau mengubah cara pandang terhadap dunia dan bagaimana mengubah dunia itu sendiri".

Bourdieu (2010: 22; Gajdosova, 2008: 87-88) menyebut bahwa taruhan utama dalam arena sastra adalah monopoli legitimasi sastra, yakni monopoli kekuasaan untuk mengatakan berdasarkan otoritas siapa yang berhak menyebut dirinya penulis yang mana salah satunya ditunjukkan oleh pergulatan antara penulis muda dan penulis senior yang sudah terkonsekrasi. Penulis muda relatif belum memiliki legitimasi dan sedang berusaha memburu legitimasi tersebut. Perburuan atas legitimasi tersebut adalah praktik sastra, suatu praktik yang di dalamnya terakumulasi modal dan strategi-strategi tertentu yang berimplikasi pada perubahan struktur arena. Pada saat dan struktur yang sama, penulis senior berusaha mempertahankan legitimasi dan posisi yang ia miliki dalam arena tersebut. Bourdieu (2010: 26) menegaskan "inisiatif perubahan nyaris selalu diawali oleh pendatang baru, yaitu generasi muda, yang juga paling sedikit memiliki modal spesifik. (...) Mereka harus menegaskan keberbedaan mereka, membuatnya diketahui dan diakui (mencetak nama untuk diri mereka sendiri). Untuk itu mereka mengupayakan penekanan cara-cara berpikir dan doksa baru, menyuarakan kerancuan, keburaman, dan ketidaktepatan ortodoksi."

Bourdieu menjelaskan proses terjadinya atau mekanisme kuasa simbolik ini melalui apa yang disebutnya 'doksa', yakni “seperangkat kepercayaan fundamental yang bahkan dirasa tidak perlu dieksplisitkan, seakan suatu dogma" (Bourdieu, dalam Deer, 2008: 120). Dengan kata lain, doksa adalah suatu kepercayaan yang diterima apa adanya, tidak pernah dipertanyakan, yang telah mengarahkan cara pandang seseorang dalam mempersepsi dunia atau arena dimana doksa tersebut berada. Proses kuasa simbolik terjadi saat otonomi arena tersebut melemah sehingga memungkinkan munculnya suatu pemikiran lain yang disampaikan agen-agen dalam arena tersebut untuk mempertanyakan, menantang, atau bahkan menggantikan doksa yang dimaksud.

Bourdieu (1995: 168-9) menyebut pemikiran 'yang-menantang' tersebut sebagai heterodoksa, yakni pemikiran yang disampaikan secara eksplisit yang mempertanyakan sah atau tidaknya skema persepsi dan apresiasi yang tengah berlaku. Pada saat yang sama, kelompok dominan yang memiliki kuasa atau kontrol tertentu akan berusaha mempertahankan struktur arena yang didominasinya dengan memproduksi apa yang disebut dengan ortodoksi, yakni pemikiran yang secara eksplisit membela atau mencoba mempertahankan 


\section{Jurnal Poetika Vol. III No. 2, Desember 2015}

struktur serta aturan dalam arena tersebut. "Kelas yang terdominasi," tegas Bourdieu (1995: 169), "memiliki kepentingan untuk melawan batas-batas doksa dan menunjukkan kearbitreran dari sesuatu yang dipahami secara apa adanya; kelas yang mendominasi memiliki kepentingan untuk mempertahankan integritas doksa menjaga keberlangsungan arena melalui ortodoksa." Dengan demikian, kuasa simbolik mengambil bahasa sebagai bentuknyapernyataan tentang aturan atau hal-hal yang berlaku dalam suatu arena. Kuasa simbolik merupakan bagian dari praktik sosial secara keseluruhan: ia beroperasi dan dioperasikan oleh agen-agen dalam arena-arena dalam ruang sosial termasuk arena sastra.

Dalam kerangka berpikir pertarungan simbolik serupa itulah kiprah AH dalam arena sastra Indonesia akan coba dijelaskan dalam artikel ini. Lebih spesifik, artikel ini membahas pandangan seperti apa yang coba dihadirkan dan dikontestasikan oleh $\mathrm{AH}$ dalam praktik sastranya di arena sastra Indonesia.

\section{Pembahasan}

Sebagai penulis yang relatif baru, Andrea Hirata tidak banyak terlibat dalam konstelasi arena sastra Indonesia. Andrea tidak bergabung dengan institusi-institusi sastra legitimit yang umumnya berbentuk komunitas seperti Teater Utan Kayu (TUK), Forum Lingkar Pena, serta tidak pernah mempublikasikan karya melalui institusi media penerbitan seperti Majalah Horison, Kompas, dan Gramedia Pustaka Utama. Kemunculan novel Laskar Pelangi, yang banyak dipercaya sebagai karya yang 'tidak sengaja diterbitkan', menuai apresiasi tinggi dari masyarakat. Sejak itu, nama Andrea Hirata perlahan mulai dikenal, meski ketidakterlibatannya pada institusi sastra legitimit di Indonesia, pada tahap-tahap tertentu, berimplikasi pada status 'kesastrawanan' atas dirinya. Seperti pernyataannya, "apabila kita mengatakan bahwa seseorang mesti punya background sastra untuk bisa menulis, kemudian seseorang mesti punya pengalaman menulis untuk bisa menulis, misalnya, ternyata dalam pengertian tertentu itu bisa tidak relevan" (transkripsi wawancara Andrea Hirata dengan Hernowo dalam acara "Mengikat Makna", 28 November 2007, Bandung).

Lebih jauh, ketidakterlibatan pada institusi sastra legitimit rupanya bukan suatu hal yang tidak disengaja oleh $\mathrm{AH}$, melainkan suatu sikap yang didasarkan atas pertimbangan tertentu. Hal tersebut tercermin dari pernyataanpernyataannya tentang arena sastra Indonesia.

Andrea Hirata bisa dikatakan sebagai novelis yang cukup sering memberi pernyataanpernyataan terkait arena sastra Indonesia. Meski begitu, pernyataan yang ia sampaikan terkesan bersifat umum daripada spesifik, dan strategis, dalam arti pernyataan tersebut disampaikan sebagai bagian dari caranya untuk menjelaskan posisi diri serta karyanya. Andrea (dalam Asrori, 2008: 212) mengatakan, "Sastra di Indonesia ini setengah mati eksisnya, bergiat dalam sastra nggak dihargai." Lebih lanjut, Andrea (dalam Asrori, 2008: 208) menyatakan, "Saya pernah tinggal di Inggris, pernah tinggal di Perancis, saya melihat bagaimana sastrawan di sana menjadi bagian dari komunitas yang sangat terhormat. Sementara kita di sini tenggelam dalam lubang narsisme kita, bahwa makin kumuh makin hebat, menulis buku dibaca dua orang sudah dikatakan karya sastra hebat."

$$
\text { Kutipan tersebut setidaknya }
$$
mengimplisitkan tiga hal yakni, pertama, Andrea menganggap sastra terkait dengan kehormatan atau gengsi dan bentuk-bentuk simbolik; kedua, Andrea membedakan antara sastra Eropa, dalam hal ini Inggris dan Perancis, dengan sastra Indonesia secara bertingkat. Jika sastra di Eropa dipahami dan berada pada kondisi terhormat, sastra 'kita', dalam hal ini Indonesia, berada pada kondisi kumuh dan narsistik; ketiga, Andrea sekaligus menunjukkan posisi dirinya yang, dalam perspektif Bourdieu (2010: 38-40), berada dalam subarena produksi skala-besar yang keberhasilannya diukur dari pencapaian 


\section{Jurnal Poetika Vol. III No. 2, Desember 2015}

laba material atau ekonomi. Artinya, Andrea berpendapat bahwa sastra mengandung dimensi kehormatan sekaligus keuntungan materi sebagai kompensasi yang didapat penulis. Pendapat tersebut, seperti akan terlihat di uraian berikut, merembesi praktiknya dalam membaca ruang-ruang kemungkinan di arena sastra Indonesia maupun ruang sosial yang bisa ia raih sesuai dengan kepentingan simbolik dan material tersebut di atas.

Andrea memandang Sastra Indonesia masih terjebak dalam apa yang dia sebut paradigma lama. Andrea menganggap karya sastra yang ditulis sastrawan Indonesia masih berkutat pada aspek-aspek intrinsik yang menurutnya tak lagi relevan. Hal itu tampak pada pernyataannya, "apabila kita percaya dalam paradigma lama dalam menilai sebuah sastra yang baik kita akan tersesat sendiri. Saya membaca itu dalam paradigma lama percaya dengan penokohan, percaya dengan plot, metafora, percaya dengan karakterisasi, komposisi, dialog. Sekarang paradigma itu bubar. (transkripsi wawancara Andrea Hirata dengan Hernowo dalam acara "Mengikat Makna”, 28 November 2007, Bandung)

Andrea mengatakan sastra semacam itu hanya akan menghasilkan bahasa-bahasa sastrawi yang meninabobokan pembaca tanpa membuka otak untuk berpikir konteks. Arena sastra Indonesia, yakinnya, dipenuhi oleh karyakarya semacam itu. "Tiga juta buku sastra kita sudah menulis begitu (Andrea, dalam Asrori, 2008: 55)." Implisit dalam pernyataan itu, Andrea sudah menyiapkan diri dan karyanya untuk 'tampil-beda' yang dalam istilah Bourdieu (2010: 49) disebut 'membuat tanda sendiri' demi datangnya pengakuan atas keberbedaan dari produsen lain yang legitimit.

"Tanpa data anglenya di situ-situ saja. Anglenya itu saja, selalu seremonial. Perhatikan, tulisan-tulisan bertema kultur di Indonesia selalu seperti ini: pertama seremonial, kedua tabu, ketiga culture shock, adanya pengaruh budaya baru, dan lainnya, keempat berhubungan dengan hukum atau adat istiadat, seperti tanah, pemerintahan, apa segala macam, selalu begitu dan tidak pernah berkembang. Yang paling banyak tentang tabu. Sebuah tabu yang dilanggar lalu jadi novel. Selalu begitu." (wawancara dengan klubbaca)

Kutipan tersebut menunjukkan Andrea menantang, bahkan menyerang, doksa atau semesta wacana yang ada dan tidak dipertanyakan dalam arena sastra Indonesia. Andrea tampak berhati-hati dengan ruangruang kemungkinan yang seakan 'tersedia' dan diamini oleh agen-agen sastra dalam struktur arena. Andrea seakan tidak ambil pusing dengan perdebatan tentang 'sastra-universal' dengan 'sastra-kontekstual' serta empat 'jenis' sastra di Indonesia yakni: (1) sastra yang diresmikan atau dilegitimasi; (2) sastra terlarang; (3) sastra yang diremehkan; dan (4) sastra yang dipisahkan, seperti pernah dipaparkan oleh Ariel Heryanto (1985: 4-7). Pernyataan Andrea yang tersebut di atas seakan-akan menunjukkan pandangan yang menolak atau tidak sepakat dengan karyakarya 'sastra-universal' yang berorientasi pada pencapaian estetika sehingga dipenuhi teknik serta akrobat kebahasaan namun menjauh dari konteks masyarakatnya. Namun, pernyataan tersebut juga tidak berarti Andrea memilih berada pada posisi 'sastra-kontekstual' yang dekat dengan kritik sosial serta bernuansa politis. Andrea (dalam Asrori, 2008: 207) mengungkapkan hal itu "Laskar Pelangi ingin clear dari politik".

Alih-alih larut dalam doksa dalam arena sastra Indonesia serupa itu, Andrea mencoba menawarkan pandangan (heterodoksa) yang disebutnya sebagai possibility, yakni karya sastra yang di dalamnya "tidak ada satu rumusan untuk sebuah buku yang bagus. Namun ada kecenderungan buku yang sukses, yakni karena possibilitynya, (...) yakni mengandung science, mengandung estetika, mengandung semiotika, menantang saya, memojokkan saya, menyadarkan saya. Possibility. Karena possibility-nya tadi penulis itu demikian hebatnya 


\section{Jurnal Poetika Vol. III No. 2, Desember 2015}

meletupkan simptom-simptom di kepala pembaca." (transkripsi wawancara Andrea Hirata dengan Hernowo dalam acara "Mengikat Makna”, 28 November 2007, Bandung).

Possibility yang dimaksud Andrea sesungguhnya mengarah pada fungsi karya sastra sebagai pemberi motivasi pembaca untuk 'maju'. Karya-karya Andrea, seperti ditunjukkan Sang Pemimpiyang terurai dalam bab sebelumnya, menunjukkan suatu narasi tentang tokoh-tokoh yang mencapai keberhasilan tertentu yang dikemas dengan gaya realisme formal. Pandangan possibility yang dibalut dalam gaya realisme formal tentang nilai-nilai 'motivatoris' tersebut terus dipertandingkan dalam arena sastra Indonesia, melawan ortodoksa kelompok-kelompok legitimit yang masih beranggapan bahwa sastra bukanlah vulgaritas penyampaian nilai-nilai melainkan pada keterampilan atau teknik berbahasa yang mengarah pada implisititas makna.

\section{Realisme Formal}

Dalam pemahaman Bourdieu, pergulatan sastrawan melalui karya sastra sesungguhnya pergulatan dalam hal tema. Bourdieu (2010: 147) memahami tema bukan sekadar topik cerita, lebih dari itu, tema dipahami "sebagai caracara artistik yang spesifik yang dipakai seniman dalam menggengam dunia, tanda-tanda yang tak bisa disangkal mengenai penguasaannya terhadap seni". Artinya, tema merujuk pada metode kreatif yang menunjukkan keterampilan tertentu dalam penciptaan karya. Dalam karya sastra, keterampilan tersebut, yang sekaligus juga modal kultural sastrawan, terutama mengacu pada kemampuan literer yang melibatkan teknik berbahasa serta kemampuan memainkan jarak antara imajinasi dan kenyataan.

Jika dicermati, AH sesungguhnya mengusung apa yang Ian Watt (1968: 33) sebut sebagai konvensi realisme formal yang mana "novel dipahami sebagai laporan otentik tentang pengalaman manusia dan di samping itu, novel berada dalam keharusan untuk memuaskan pembacanya dengan sekian detil cerita terkait kepentingan individual tokohnya, kekhususan waktu dan tempat dari aksi-aksinya, yang mana detil tersebut dihadirkan melalui bahasa yang mudah dicerna, umum, mengacu secara langsung kepada referennya yakni kehidupan." Watt juga menjelaskan bahwa realisme formal sebagai konvensi naratif novel berbeda dengan genre lain dalam sastra yang cenderung memaparkan dunia antah-berantah, permainan bahasa yang teramat canggih yang justru mengaburkan referensial yang diacu oleh karya sastra; sebaliknya, penulis novel "aim is to make the words bring his object home to us in all its concrete particularity, whatever the cost in repetition or parenthesis or verbosity" (Watt, 1968: 30).

Realisme formal merupakan konvensi novel paling awal yang mana berdasarkan konvensi tersebut novel dibedakan dari prosa (fiksi) yang muncul sebelumnya (Watt, 1968: 10). Secara epistemologis, realisme formal tidak terlepas dari filsafat modernisme dan peradaban modern yang mana harkat manusia kembali lagi menjadi subjek yang mengontrol alam, otonom, pusat yang darinya kehidupan dialami sekaligus diubah, yang dalam Watt (1968: 15) setara dengan cogito ergo sum yang menjadi kredo Rene Descartes. Artinya, realisme formal berkait erat dengan tokohtokoh yang 'hebat' yang mampu mengatasi segala rintangan dalam hidupnya, yang mana pengalaman-pengalaman tersebut menjadi unsur terpenting dalam teks sastra. Watt (1968: 18-19) secara tegas menunjukkan relasi antara filsafat modern dan realisme formal yakni, jika problem filsafat adalah mendefinisikan manusia secara individual, maka penulis novel beraliran ini juga berkepentingan menampilkan individualisasi karakter lengkap dengan detil pengalaman, lingkungan, yang bahkan tak jarang nama dari tokoh atau karakater itu sama persis dengan nama individu dalam dunia nyata yang dirujuknya. Pengalaman tersebut, sekali lagi, ditampilkan dalam bahasa yang 'jelas', yang langsung merujuk pada dunia sehari-hari. 


\section{Jurnal Poetika Vol. III No. 2, Desember 2015}

Dalam Sang Pemimpi, dan juga karyakaryanya yang lain, Andrea konsisten dengan dengan gaya penulisan realisme formal ini. Andrea seakan-akan memindah dan menuliskan pengalaman hidupnya ke dalam suatu teks yang dalam banyak hal sama sekali tidak mengubah referen cerita yang diacunya. Hal tersebut misalnya tampak pada pemilihan nama: tokohtokoh di dalam karyanya adalah juga tokoh dalam dunia nyata dengan nama, kisah, dan ciri fisik yang sama. 'Bu Muslimah' dalam teks adalah juga $\mathrm{Bu}$ Muslimah dalam dunia sebenarnya, berikut tokoh-tokoh lainnya. Dalam aspek latar, Andrea juga mendeksripsikan setiap detil tempat, benda, kebiasaan, dan atribut-atribut Belitung sesuai ingatan yang mengendap dalam ingatannya. Hal tersebut dia jelaskan dalam suatu wawancara:

"Karena ini terlalu cultural...bahwa karena pengamatan saya, saya menggambarkan orang detail. Orang bilang, Andrea, membaca bukumu seperti melihat gambar. Karena sampai setiap orang, tinggi badannya, apa, sebuah tempat, sampai bunga ini ada di situ. Jadi, membaca itu dimensional. Seperti Anda memasuki sebuah ruangan, saya gambarkan kepada Anda setiap sudut. Akhirnya, Anda terorientasi di ruangan itu. Itu teknik menulis. Ya sehingga deskripsi Anda masuk, Anda seperti di situ. Karena tanpa Anda sadari saya mengatakan di sudut kanan atas ada sebuah kursi, di sudut kiri ada televisi. Tanpa pembaca sadari, saya menciptakan dimensi." (transkripsi diskusi Andrea Hirata dalam acara Menembus Sastra Dunia Bareng Andrea Hirata, Gedung America Pasific Place, Jakarta, 31 Maret 2012)

Dari kutipan tersebut dapat diketahui bahwa Andrea memang menyadari, bahkan menjadikannya sebagai suatu teknik menulis yang ia terapkan dalam karyakaryanya. Meskipun terkesan berlarat-larat, membosankan, dan tentunya panjang, Andrea menegaskan hal tersebut memang diperlukan karena dirinya memposisikan diri sebagai penulis yang mengusung 'perspektif kultural'.
Perspektif tersebut, ujar Andrea, membutuhkan detil dan kecermatan dalam melukiskan setiap peristiwa yang dituliskan.

"Saya menulis Padang Bulan itu, itu empat tahun riset culture-nya. Itu banyak sekali bab tentang mengamati orang minum kopi di warung kopi. This is very cultural sebenarnya ya. Bagaimana orang Melayu tuh bisa digambarkan kepribadian dengan cara dia memegang gelas kopi. Ada yang megangnya begini, berarti ia sedang gugup. Ada yang megangnya gini, utangnya banyak. Tapi, tentu saja disembunyikan. Ada yang begini, dia genit. Sampai bentuk bagaimana jari dia memegang gelas kopi diriset gitu. Itu culture loh. Itu saya kira jawabannya." (transkripsi diskusi Andrea Hirata dalam acara Menembus Sastra Dunia Bareng Andrea Hirata, Gedung America Pasific Place, Jakarta, 31 Maret 2012).

Dalam arena sastra Indonesia khususnya novel, gaya realisme formal boleh dikatakan identik dengan novel populer. Jakob Sumarjo (1980: 18) menyebut novel populer sebagai novel yang dalam hal tema, cara penyajian, teknik, bahasa maupun gaya meniru pola yang sedang digemari masyarakat pembacanya. Novel dalam kategori ini umumnya mudah dipahami karena kisahnya tentang kehidupan seharihari, bahasa yang jernih dan plot yang lurus atau konvensional yang mana nilai-nilai moral disampaikan secara eksplisit sesuai dengan gaya penulisan yang dipilihnya. Meskipun pendapat tersebut banyak mendatangkan kritik dalam konteks kekinian, namun tidak bisa dipungkiri bahwa penulis yang mengusung realisme formal seperti Andrea Hirata kualitasnya masih dianggap di bawah penulis yang mengusung gaya penulisan lain seperti Seno Gumira Ajidharma, Agus Noor, Ayu Utami, dan lainnya, yang katakanlah lebih akrobatik secara kebahasaan, cerita, maupun isu yang dimunculkan.

Gaya penulisan realisme formal yang diusung Andrea, dalam konteks arena sastra kekinian, harus bersaing dengan gaya yang diusung novelis-novelis yang telah mendapat 


\section{Jurnal Poetika Vol. III No. 2, Desember 2015}

legitimasi. Gaya penulisan itu setidaknya bisa disimak dalam uraian Korrie Layun Rampan (2000: xlvii-ix) terkait sastrawan angkatan 2000, yang mana nama-nama novelis berikut gaya penulisan atau orientasi estetiknya dideskripsikan:

"Pembaruan Seno tampak dari pilihannya terhadap model sastra lisan yang mengembalikan realitas fiktif kepada realitas dongeng. (...). Seno memaparkan sifat fiksionalnya dalam tragedi yang diselubungi dunia dongeng (...), realitasnya yang dibangunnya kadang surealistik dan absurd, tetapi tokoh-tokoh itu terasa realistik, karena dibangun dari kenyataankenyataan faktual. Estetik baru yang dikembangkan secara menarik oleh Seno adalah perkembaliannya terhadap sastra murni yang tidak memisahkan antara wacana prosa dan puisi. Meskipun kadang amanat menjadi sayup dalam wacana yang liris, keindahan yang dimunculkan oleh bias-bias pikiran secara intens menyorotkan kecerahan dan pencerahan, terutama karena pemasukan unsur-unsur peristiwa hitam dan kritik sosial".

Lebih jauh, Korrie menyebutkan beberapa nama novelis dan cerpenis lain dalam sastra Indonesia yang dianggap memiliki capaian estetik tertentu dalam hal gaya penulisan yang legitimit dan karenanya bisa dikategorikan sebagai sastra-serius. Agus Noor, misalnya, mampu menyajikan peristiwa-peristiwa irrasional dan sensasional melalui bahasa yang metaforis. Narasi yang dibangun juga terkesan 'serius' dan 'berat' yang terpapar secara komikal seperti diusung oleh Ahmadun Yosi Herfanda atau gaya psikotik yang diusung Sony Karsono yang mana "arus kesadaran dalam lewat pengembangan dunia psikologi dan sejarah kebudayaan yang memungkinkan tokohtokohnya muncul secara realistik, meskipun dunia yang dikembangkannya merupakan dunia dongen, (...) pembebasan masa lalu dan masa datang ke dalam realitas masa kini, perumitan pengucapan naratif yang memesona, dengan perimbangan dongeng kontemporer yang terus menerus mengundang keingintahuan tanpa kesabaran." (Korrie, 2000: liii)

Pencarian estetik yang tidak lagi berkutat pada realisme formal boleh disebut sebagai genesis arena sastra khususnya novel, yang dengannya seorang penulis bisa mendapatkan apa yang Bourdieu sebut sebagai legitimasispesifik, yaknipengakuan yang didapat dariagenagen sastra. Dalam tataran inilah gaya realisme formal Andrea Hirata dianggap 'usang', populis, dan kalah 'berharga' dibandingkan penulis lain seperti tersebut di atas. Karya-karya Andrea yang mengusung tema remaja dan pendidikan juga bisa disebut memperkuat citranya sebagai penulis populer, atau setidaknya penulis dengan modal kultural yang lemah dibanding penulis lain yang mampu memeragakan keterampilan berbahasa yang relatif lebih 'canggih' daripada dirinya.

Rendahnya legitimasi dari agen-agen sastra di Indonesia itu terlihat, misalnya, dari komentar atau tanggapan atas karya yang dihasilkannya. Andrea lebih banyak mendapat tanggapan dari agen-agen di luar sastra, misalnya presenter televisi, aktivis, maupun tokoh masyarakat yang bukan dari agen sastra. Dalam endorsment yang terdapat dibukunya, Sapardi Djoko Damono menuliskan, "Ramuan pengalaman dan imajinasi yang menarik yang menjawab inti pertanyaan kita tentang hubungan-hubungan antara gagasan sederhana, kendala, dan kualitas pendidikan."

Sapardi memberikan penekanan pada kata 'sederhana' untuk menjelaskan karya-karya Andrea Hirata, baik secara gagasan maupun teknik penulisan. Hal tersebut berbeda saat Sapardi memberikan komentarnya tentang novel Saman tulisan Ayu Utami, "Dahsyat. (...) memamerkan teknik komposisi yang-sepanjang pengetahuan saya-belum pernah dicoba pengarang lain di Indonesia, bahkan mungkin di negeri lain."

Andrea lebih banyak mendapat pujian dari tokoh-tokoh seperti Andi F. Noya, presenter televisi yang cukup terkenal, mengatakan karya 


\section{Jurnal Poetika Vol. III No. 2, Desember 2015}

Andrea sebagai "sebuah novel yang sangat menginspirasi. Siapa pun yang membacanya akan termotivasi dan merasa berdosa jika tidak mensyukuri hidup". Komentar tersebut lebih melihat karya Andrea sebagai suatu teks dari aspek pragmatisnya, yaitu 'memberi inspirasi'; dan sama sekali tidak menyentuh aspek estetika karyanya. Pernyataan serupa juga disampaikan Achmad Syafii Maarif, mantan ketua PP Muhammadiyah, yang mengatakan bahwa Sang Pemimpi "Tidak kalah kocak dibandingkan LaskarPelangi. Tuturannya mengalir, menyentuh, mencerahkan, menggelikan, membidik pusat kesadaran, dan jauh dari sifat menggurui." Tokoh-tokoh lain yang memberikan komentar adalah Kak Seto yang lebih dikenal sebagai pakar pendidikan, Garin Nugroho (sutradara film), Nicola Horner (jurnalis The Guardian, London-Inggris).

Secara lebih tegas, Andrea menyebut praktik mengarang yang dilakukannya berangkat dari apa yang dia sebut sebagai 'perspektif kultural' yang mana hanya dapat dilakukan dengan kerja riset yang mumpuni. Bagi Andrea "Menulis itu adalah meletakkan sesuatu dalam perspektif. Udah titik, itu saja. Ya, kan? Kalau saya menulis tentang saya, sangat mencintai ayah saya, banyak dalam tulisan saya, itu nggak akan berbunyi apa-apa kalau tidak ada perspektifnya." Perspektif tersebut, menurut Andrea, adalah perspektif budaya yang dapat diartikan sebagai suatu sudut pandang yang menjadikan segala peristiwa sebagai suatu peristiwa budaya. Andrea berkeyakinan bahwa hanya dengan perspektif kultural inilah sastrawan Indonesia mampu bersaing dalam arena sastra dunia. Hal tersebut dia tegaskan dan yakini setelah mempelajari kecenderungan tema karya sastra yang ditulis oleh sastrawan mancanegara.

“..ternyata tulisan begini yang diminati internasional, kalau kita ingin going global. Karena ketika kita nulis romance kita itu selalu kalah dengan penulis Italia. Ketika kita menulis sains fiction, disikat sama Dan Brown semua, kita nggak ada peluang.
Mungkin kalau ada penulis Indonesia yang jenius sekali bisa menggarap tematema sains fiction. Ketika kita menulis tentang ironi ekonomi, budaya, penulispenulis India tampil nomor satu. Penulis kita apa? culture. Tulisan-tulisan culture saya kira." (transkripsi diskusi Andrea Hirata dalam acara Menembus Sastra Dunia Bareng Andrea Hirata, Gedung America Pasific Place, Jakarta, 31 Maret 2012).

Pernyataan tersebut serentak menunjukkan orientasi praktik sastra Andrea yakni, pertama, pada gaya realisme formal yang mana deksripsi detail dari setiap aspek dalam karya menjadi unsur yang diutamakan. Bahasa yang jelas, eksplisitas deskripsi dan pesan, serta tokoh-tokoh yang tangguh menghadapi dan memenangkan setiap ujian menjadi strategi literer Andrea dalam berkarya. Strategi itu dipilihnya karena dirinya telah membaca dan mempelajari karakteristik pembaca Indonesia yang menurutnya "semua harus dijelasin dan mereka suka karena kita bangsa penonton, bukan bangsa pembaca. Ketika budaya literal kita belum, literatur kita belum tumbuh, kita diserang televisi. Maka kita ini bangsa penonton, orang Indonesia, sehingga tulisan yang deskriptif disukai." (transkripsi diskusi Andrea Hirata dalam acara Menembus Sastra Dunia Bareng Andrea Hirata, Gedung America Pasific Place, Jakarta, 31 Maret 2012).

Kedua, meskipun mengusung realisme formal yang seakan nyaris tak berjarak dengan kenyataan dan membuatnya tidak mendapat legitimasi spesifik dari agen sastra di Indonesia, Andrea bisa dikatakan cukup cerdik untuk memilih tema-tema kultural atau lokalitas yang relatif lebih banyak diusung sastrawansastrawan legitimit, dan menghindari tematema Islami atau remaja metropolitan seperti banyak diusung dalam novel-novel chicklit atau teenlit. Dalam karya-karyanya, termasuk Sang Pemimpi, Andrea selalu mengedepankan aspek 'Belitung' sebagai suatu daerah terpencil dengan keunikan budaya tertentu, dalam hal ini etnik Melayu. Masalah-masalah yang dihadapi daerah 


\section{Jurnal Poetika Vol. III No. 2, Desember 2015}

terpencil, khususnya pendidikan, dihadirkan lengkap dengan detail latar dan ungkapanungkapan khas etnis tersebut. Andrea berusaha tidak secara vulgar mengikuti arus utama sastra remaja atau Islami yang dalam struktur arena sastra memang bukan termasuk karya yang mendapatkan legitimasi spesifik. Ketiga, pernyataan Andrea bahwa proses kreatifnya dalam sastra Indonesia yang dilakukan sejak dan karena bencana tsunami Aceh 2004, pada tahap-tahap tertentu bisa dibaca sebagai suatu sensitivitas yang mana sensitivitas tersebut diproyeksikan ke dalam karyayangdihasilkannya. Sensitivitas yang dimaksud adalah pada kondisi psikologis masyarakat Indonesia pasca Orde Baru yang masih berada pada fase membangun tatanan masyarakat dan sosial-politik. Di satu sisi, kebebasan bereskpresi memunculkan kemeriahan tertentu dalam dinamika sosial, namun di sisi lain tidak jarang kondisi tersebut memunculkan banyak permasalahan dan kebingungan tentang bentuk formasi sosial dan tatanan kehidupan. Bencana alam yang terjadi silih-berganti juga menciptakan kondisi mental tertentu yang cenderung depresif. Melalui karya-karyanya, Andrea menghadirkan cerita yang memberi motivasi, makna perjuangan individu, dan narasi keberhasilan yang direspon positif oleh masyarakat.

\section{Sastra-'Sinematik'}

Belum didapatkannya legitimasi spesifik dalam arena sastra Indonesia membuat Andrea berinisiatif untuk mempertajam figurnya sebagai novelis yang berpengaruh luas. Film dipilihnya sebagai media transformasi karyakaryanya, dengan tujuan mampu meraih perhatian dan pengakuan tertentu dari publik seluas-luasnya.

Andrea sangat menyadari modal yang dimilikinya. Gaya penulisan realisme formal dalam karya-karyanya relatif mudah ditransformasikan ke dalam film. Hal itu disampaikan Andrea, "Di dalam buku, dengan sekali saja ditampilkan pembaca akan tahu.
Kemudian di dalam benaknya, pembaca menghidupkan theatre of mind. Cerita itu sudah bergerak sendiri dalam kepalanya, dia punya panggung sandiwara di kepalanya. Itu pula mengapa banyak orang yang mengatakan kalau membaca Laskar Pelangi seperti menonton film.” (dalam Budiarti, 2009: 18).

Pada Agustus 2010, setelah rentetan penghargaan atas film-film hasil transformasi karyanya yang disutradarai Riri Riza, sineas Indonesia yang dikenal memiliki jaringan luas di perfilman internasional, Andrea mendapatkan undangan sebagai peserta untuk mengikuti program International Writing Program di University of Iowa. Program tersebut merupakan program sekolah penulisan yang prestisius dan diikuti oleh tiga belas sastrawan dari beberapa negara. Keikutsertaan Andrea dalam program tersebut merupakan fase penting atau apa yang oleh Bourdieu (2010: 58) disebut sebagai titik kritis dalam trajektorinya sebagai novelis. Meskipun di Indonesia dirinya belum mendapat legitimasi spesifik, tidak banyak terlibat dalam acara-acara sastra yang legitimit, dan tidak tergabung dalam kelompok-kelompok sastra yang 'hegemonik', Andrea mampu menembus program penulisan yang sekaligus juga penanda kiprahnya dalam arena sastra di skala internasional. Andrea terpilih sebagai salah satu dari 13 penulis dari 90 penulis di dunia yang mengikuti seleksi beasiswa tersebut (Lee dan Strenagel, 2010: xiv).

Dalam program tersebut, Andrea juga mendapat modal sosial serta kultural dalam arena sastra, yakni jaringan penerbit internasional serta materi terkait penulisan karya sastra. Program tersebut memberikan apa yang Andrea sebut sebagai pengetahuan 'riset budaya' dalam penulisan sastra yang menurutnya masih jarang dilakukan penulispenulis yang berasal dari Indonesia.

"Broadly speaking, the program has given me with two important things: how to apply the methodology of cultural research, especially in research of how to write a novel with culture theme; and second is the fact that it gave me insights on how to write novels that are aimed at a 


\section{Jurnal Poetika Vol. III No. 2, Desember 2015}

wider audience (global)." (jakarta.usembassy. gov)

Secara umum, program ini telah memberiku dua hal penting: bagaimana mengaplikasikan metodologi dalam riset budaya, khususnya riset tentang bagaimana menulis novel dengan tema kultural; dan kedua adalah fakta bahwa program tersebut memberiku gambaran tentang bagaimana menulis novel-novel yang ditujukan untuk audiens secara luas (global). (jakarta.usembassy.gov)

Pengetahuan yang disebut Andrea sebagai riset-kultural ini analog dengan apa yang disebut Bourdieu sebagai modal kultural yang harus dimiliki oleh seseorang ketika bertarung dalam suatu arena. Modal kultural tidak bisa dibeli atau diwariskan, melainkan dipelajari dalam satu rentang waktu tertentu, yang mana berdasarkan modal inilah penulis menghasilkan suatu karya tertentu. Andrea yang sebelumnya dididik dalam disiplin ilmu sains dan selalu mengatakan tidak pernah belajar menulis secara formal seakan menemukan suatu fase dirinya ditempa secara khusus dan fokus terkait praktik penulisan sastra.

Selain mendapat kontribusi dalam hal akumulasi modal kulturalnya, Andrea dalam program ini juga mendapat kontribusi dalam modal sosial, dalam artian jaringan penerbit internasional. Dalam rentang waktu yang tidak begitu lama pasca keikutsertaannya pada program tersebut, karya-karya Andrea banyak mendapat tawaran untuk diterbitkan penerbitpenerbit internasional. Dalam rentang waktu akhir 2010 hingga 2012, karya-karya Andrea sudah diterjemahkan ke dalam 23 bahasa asing dan terbit di beberapa negara seperti Jerman, Portugal, China, Vietnam, Korea, dan Brazil (lampungpost.com, 26 Oktober 2012). Salah satu penerbit internasional yang menerbitkan karya Andrea adalah penerbit terkemuka di Amerika Serikat, Farrar, Strauss and Giroux (FSG). Terkait dengan capaian dalam trajektori kepenulisannya itu, Andrea mengatakan "Butuh waktu empat tahun untuk bisa menembus penerbit itu. Penerbit itu bukan sembarang penerbit. Banyak peraih nobel yang karyanya diterbitkan oleh penerbit itu. Buku yang diterbitkan pun setelah melalui seleksi ketat." (antaranews.com). Andrea menegaskan bahwa hal tersebut sudah sesuai dengan alurnya yang menganggap menulis sebagai profesi dan karenanya hendak menjangkau pasar seluasluasnya. Hal itu, menurut Andrea "sangat bermakna. Kamu lihat dari dimensi apapun. Coba kita lihat dari dimensi industri buku, tidak pernah ada sebelumnya buku dari Indonesia diterbitkan world class publisher. Itu something. Kemudian, dia terbit di New York, juga tidak pernah ada sebelumnya buku Indonesia terbit di New York. Itu dimensi dalam pencapaian itu dari industri. Kalau diterbitkan di New York akan membuka kemungkinan, dan memang terbuka diterbitkan di banyak negara." (transkripsi wawancara pribadi dengan penulis, 26 Mei 2012).

Berdasarkan analisis di atas, dapat diketahui bahwa, pertama, modal kultural yang dimiliki Andrea Hirata untuk bertarung dalam arena sastra Indonesia adalah kemampuannya dalam menulis realis yang cenderung mengarah pada gaya realisme formal. Gaya penulisan ini, seperti diuraikan di atas, bukanlah gaya penulisan yang termasuk dalam kategori sastra-legitimit, melainkan lebih mengarah pada karya sastra yang mendapat legitimasi populer dan borjuis, dalam arti melayani selera kelompok dominan dalam arena kekuasaan; kedua, melalui realisme formal ini pula Andrea membangun strategi literernya dengan mengacu pada problemproblem faktual kekinian dalam ruang sosial Indonesia pasca Orde Baru yang diformulasikan dalam tema pendidikan seperti terlihat dalam novel Sang Pemimpi; ketiga, transformasi menjadi kunci strategi Andrea dalam meraih legitimasi dalam arena sastra Indonesia. Transformasi dari novel ke dalam bentuk film memberi pengaruh signifikan terhadap trakjektori Andrea dengan meraih legitimasi populer dari publik maupun dari pemerintah yang ditunjukkan dengan 


\section{Jurnal Poetika Vol. III No. 2, Desember 2015}

pernyataan Presiden SBY atas karya-karyanya; keempat, melalui transformasi ke media film itu pula Andrea terpublikasi di level internasional. Hal tersebut berkontribusi langsung pada kiprahnya, salah satunya ditunjukkan dengan keikutsertaannya pada program penulisan kreatif di Iowa Amerika Serikat. Dalam program itu pula Andrea mendapatkan kesempatan untuk bertarung, tidak hanya dalam arena sastra Indonesia, tetapi juga pada arena sastra global. Karena dengan mengusung gaya realisme formal dirinya tidak bisa mendapatkan legitimasi spesifik dari agen sastra di Indonesia, maka dirinya mencoba 'bertarung' dalam arena sastra dunia. Andrea mengarahkan segenap praktik bersastranya untuk mencari ruang-ruang kemungkinan di antara sastrawan mancanegara lain, demi mendapat pengakuan atau legitimasi dari publik sastra dunia.

\section{Kesimpulan}

Dalam kondisi demikian itulah Andrea Hirata terus bergulat dalam arena sastra Indonesia dan arena sastra dunia atau global. Di dalam arena sastra Indonesia, nama Andrea masih belum lepas dari stigma penulis populer. Kenyataan tersebut menggiringnya pada suatu pemikiran bahwa cara membuktikan dirinya layak mendapat legitimasi spesifik, bukan hanya legitimasi populer dan diapresiasi oleh pemerintah, melainkan juga oleh agen-agen sastra di Indonesia adalah dengan meraih nobel sastra dunia. Pada tahap tersebut sesungguhnya Andrea sedang 'mendesak' atau menantang agen-agen dalam arena sastra Indonesia lewat pandangan-pandangan tertentu; sesuatu yang oleh Bourdieu disebut dengan pertarungan simbolis yang terkait langsung dengan kekuatankekuatan kelompok-kelompok ortodoks dalam suatu arena, dalam hal ini arena sastra Indonesia. Hingga artikel ini ditulis, Andrea bisa dikatakan belum mendapat legitimasi spesifik. Namun, kontestasi simbolik merupakan sesuatu yang senantiasa terjadi; suatu proses yang di dalamnya seorang sastrawan berebut posisi.
Dengan demikian, kelak Andrea bisa saja memenangkan nobel dunia yang belum pernah dimenangkan penulis Indonesia; atau bisa juga posisinya tidak pernah berubah sebagai penulis sastra medioker yang lihai bercerita secara 'apa-adanya' dan menghibur, namun tak cukup berwibawa dalam meniupkan pemikiran yang secara terampil terajut dalam teknik bersastra yang lebih dianggap estetik.

\section{Daftar Pustaka}

Bourdieu, Pierre. 2010. Arena Produksi Kultural. Jogjakarta: Pustaka Pelajar 1986. The Form of Capital. dalam J.G Richardson (ed)

Handbook of theory and research for the Sociology of Education (New York: Greenwood Press).

1992. The Logic of Practice. Stanford: Standford University

Press

1995. Language and Symbolic Power. Cambridge: Polity Press

1996. The Rules of Art. California: Standford University Press

2006. Distinction. New York: Routledge

2011. Choses Dites: Uraian dan Pemikiran.

Jogjakarta:

Kreasi Wacana

Heryanto, Ariel. 1985. Perdebatan Sastra Kontekstual. Jakarta: Rajawali

Sumarjo, Jakob. 1980. Novel Populer Indonesia. Yogyakarta: Nur Cahaya

Budiarti, Rini Triana. 2009. Di Balik Layar Laskar Pelangi. Yogyakarta:

Bentang Pustaka

Karni, Asrori. 2008. The Phenomenon. Yogyakarta: Hikmah

Rampan, Korrie Layun. 2000. Angkatan 2000. Jakarta: Grasindo

Gajdosova, J. (2008). Literary field and the question of method-revisited.Qualitative Sociology Review, 4(2), n/a. Retrieved from http://search.proquest.com/ ocview $/ 1002334269$ ? accountid $=62692$

Gartman, D. (2002). Bourdieu's theory of cultural change: Explication, application, critique. Sociological Theory, 20(2), 255-255. Retrieved from http://search.proquest.com/ docview $/ 213360140$ ? accountid $=62692$ 